\title{
A Study of Spectrum of Adipose Tissue Tumours At A Tertiary Care Hospital, Gujarat
}

\author{
Mayuri V. Thaker and Mayuri R. Gohil* \\ Pathology Department, Government Medical College, Bhavnagar, Gujarat, India.
}

\begin{abstract}
Introduction: Adipose Tissue Tumors(ATT) are the most common benign soft tissue tumors in humans. The actual incidence of Adipose Tissue Tumors is probably higher than reported because of its insidious slow growing pattern and minimal associated symptoms.

The purpose of our study is to evaluate pattern of distribution of the adipose tissue tumours in relation to different age groups, sex and anatomical site distribution and frequency of various benign \& malignant variants.

Material and Method: The present study has been done in Histopathology section of Pathology Department of Government Medical College \& Sir T General Hospital,Bhavnagar for the period of 2 years from 01/01/2013 to 31/12/2015. Total 87 cases were studied.

Results: In the present study, adipose tissue tumours constitute $1.33 \%$ of total yearly histopathological specimens. The incidence of benign soft tissue tumours is $96.55 \%$ and that of malignant tumours is $3.45 \%$. Ratio of benign to malignant ATT is $28: 1$. Commonest age group for benign tumors was 30-50 years \& for malignant lesions above 50 yrs age. Overall incidence of adipose tissue tumors is slightly higher $(52.87 \%)$ in females in comparison of males $(47.13 \%)$. The most common benign variant of lipoma is fibrolipoma.
\end{abstract}

Conclusion: Present study concludes preponderence of Benign Adipose Tissue Tumours overall and also in females with trunk being a favourable site. Malignant tumours are common in males with lower extremities being the commonest site.

Keywords: Adipose Tissue Tumors, Benign, Malignant, Lipoma.

\section{Introduction}

Adipose tissue tumors (ATT) form the largest group of mesenchymal neoplasm in humans. Benign component i.e. lipoma contributes the major proportion whereas the malignant counterpart i.e. liposarcoma being the most common primary soft tissue malignancy. ${ }^{[1]}$ Lipomas occur more frequently in adult female patients, presumably due to their tendency to accumulate more adipose tissue and also in obese patients. Lipomas can occur in many locations singly or multiple as a part of syndrome but most commonly in the subcutaneous tissue of the head, neck, shoulders and back. They can also be found intermuscularly, intramuscularly, interosseously, associated with viscera or at a site of prior trauma. ${ }^{[2]}$ It has been suggested that blunt trauma can cause rupture of the fibrous septa and anchorage connections between the skin and deep fascia, allowing the adipose tissue to proliferate. ${ }^{[3]}$ Subtypes include conventional lipomas, fibrolipomas, angiolipomas, spindle cell lipomas, myelolipomas and pleomorphic lipomas. Cosmetic deformity or compressive symptoms usually bring lipomatous masses to medical attention earlier than rapidly growing masses in other locations of the body. ${ }^{[2]}$ Treatment of benign lesions includes complete surgical excision. Recent rapid growth, size larger than $5 \mathrm{~cm}$ and intramuscular location have all been reported to be risk factors for malignancy ${ }^{[4,5,6]}$ and require repeat examination overtime to monitor for recurrence or malignant changes. Liposarcomas, comprising $7 \%$ to $27 \%$ of all soft tissue sarcomas ${ }^{[5]}$ typically arise in the fourth to sixth decade of life. They are notorious for local recurrence, and even with attempted total resection, local recurrence rates may be as high as $50 \%$. ${ }^{[4]}$

A huge amount of literature is available addressing lipoma and other ATT but still there is paucity of research work on subtypes of ATT. Hence, this study has been conducted in a tertiary care centre, Sir. Takhtasinhji Hospital, Bhavnagar with following aims and objectives: 1) To study prevalence of adipose tissue tumors in Bhavnagar district. 2) To know frequency of benign and malignant adipose tissue tumors. \& 3) To know about association of adipose tissue tumors in relation to age, sex \& location if any.

\section{Materials and Methods}

This is a retrospective study of 87 cases of adipose tissue tumors, done in Histopathology section of Pathology Department of Government Medical College \& Sir T General Hospital, Bhavnagar for the period of 2 years from $01 / 01 / 2013$ to $31 / 12 / 2015$. All specimens (including biopsy specimen) were fixed in $10 \%$ formalin, processed 
in automated tissue processor and sections were stained with H\&E stain (Harrys hematoxylin). All relevant clinical information such as age, sex, site of lesion, other relevant history and examination findings have been collected from records and analyzed. In majority of the cases radiological investigation reports were not available. No cases of recurrence have been noted in present study.

\section{Results and Analysis}

Total 87 cases of adipose tissue tumors were studied. Out of 87 cases, 46 were females and 41 were males. Highest percentage of tumor occurrence is between 30-50 years (44.05\%) age group in both sexes followed by above 50 age group in males and between 18-30 years age group in females. (Table-1).

In present study, overall benign adipose tissue tumors (96.55\%) are more common than malignant ones. (3.45\%).

Table-2 shows that benign adipose tissue tumors are common in the age group of 30-50 years while malignant tumors are common above 50 years age group.
Table $\mathbf{- 3}$ shows that overall incidence of adipose tissue tumors and benign component is slightly higher in females $(52.87 \%)$ as compared to males $(47.13 \%)$ whereas malignant lesions occur more commonly in males $(66.67 \%)$ (Table-3). Ratio of benign to malignant ATT is 28:1.

Table-4 shows frequency of conventional lipoma, their variants \& liposarcoma respectively. Overall prevalence of conventional lipoma is $85.06 \%$ followed by fibrolipoma $(5.76 \%)$, followed by angiolipoma (3.44\%).

Trunk (47.62\%), (especially backside of trunk) is the commonest site of origin for benign ATT followed by lower extremities (23.81\%) \& upper extremities. (20.24\%) Lower extremities are the commonest site for malignant ATT. (Table-5) For simplification of analysis of average size; lesions have been divided into benign \& malignant adipose tissue lesions. Malignant tumors have larger size as compared to benign ATT. The average size of all benign ATT in our study is $4.8 \mathrm{~cm}$ as compared to malignant ATT which is of about $5.6 \mathrm{~cm}$.

Table 1: Age group wise distribution of ATT in males \& females.

\begin{tabular}{|c|c|c|}
\hline AGE GROUP (Yrs.) & MALE (\%) & FEMALE (\%) \\
\hline$<18$ & $04(9.75 \%)$ & $12.17 \%)$ \\
\hline $18-30$ & $08(19.51 \%)$ & $22(47.83 \%)$ \\
\hline $30-50$ & $16(39.02 \%)$ & $11(23.92 \%)$ \\
\hline$>50$ & $13(31.72 \%)$ & $\mathbf{4 6}(\mathbf{1 0 0} \%)$ \\
\hline TOTAL & $\mathbf{4 1 ( 1 0 0 \% )}$ \\
\hline
\end{tabular}

Table 2: Age group wise distribution of benign and malignant ATT.

\begin{tabular}{|c|c|c|c|}
\hline AGE GROUP (Yrs.) & BENIGN(\%) & MALIGNANT(\%) & TOTAL \\
\hline$<18$ & $05(5.95 \%)$ & $00(0 \%)$ & $05(5.74 \%)$ \\
\hline $18-30$ & $20(23.81 \%)$ & $00(0 \%)$ & $\mathbf{3 7}(\mathbf{4 2 . 5 2} \%)$ \\
\hline $30-50$ & $\mathbf{3 7}(\mathbf{4 4 . 0 5 \% )}$ & $00(0 \%)$ & $25(28.73 \%)$ \\
\hline$>50$ & $22(26.19 \%)$ & $03(100 \%)$ & $\mathbf{8 7}(\mathbf{1 0 0} \%)$ \\
\hline
\end{tabular}

Table 3: Sex-wise distribution of benign \& malignant ATT.

\begin{tabular}{|c|c|c|c|}
\hline SEX & BENIGN (\%) & MALIGNANT(\%) & TOTAL \\
\hline Male & $39(46.43 \%)$ & $02(66.67 \%)$ & $41(47.12 \%)$ \\
\hline Female & $45(53.57 \%)$ & $01(33.33 \%)$ & $46(52.87 \%)$ \\
\hline TOTAL & $84(100 \%)$ & $03(100 \%)$ & $87(100 \%)$ \\
\hline
\end{tabular}

Table 4: Prevalence of benign and malignant ATT.

\begin{tabular}{|c|c|}
\hline Type of lesion & No. of cases (\%) \\
\hline Benign Lipomatous Lesions & $\mathbf{8 4}(\mathbf{9 6 . 5 5 \% )}$ \\
\hline Lipoma & $74(85.06 \%)$ \\
\hline Fibrolipoma & $05(5.76 \%)$ \\
\hline Angiolipoma & $03(3.44 \%)$ \\
\hline
\end{tabular}




\begin{tabular}{|c|c|}
\hline Type of lesion & No. of cases (\%) \\
\hline Myolipoma & $01(1.15 \%)$ \\
\hline Spindle cell lipoma & $01(1.15 \%)$ \\
\hline Malignant Lipomatous Lesions & $\mathbf{0 3}(\mathbf{3 . 4 5 \% )}$ \\
\hline Liposarcoma & $03(3.45 \%)$ \\
\hline Total & $\mathbf{8 7}(\mathbf{1 0 0 \% )}$ \\
\hline
\end{tabular}

Table 5: Anatomical distribution of benign and malignant ATT.

\begin{tabular}{|c|c|c|}
\hline SITE & BENIGN LESIONS (\%) & MALIGNANT LESIONS (\%) \\
\hline Trunk & $4047.62 \%)$ & $0000 \%)$ \\
\hline Lower extremities & $2023.81 \%)$ & $03100 \%)$ \\
\hline Upper extremities & $1720.24 \%)$ & $0000 \%)$ \\
\hline Head \&neck & $078.33 \%)$ & $0000 \%)$ \\
\hline Total & $\mathbf{8 4} \mathbf{1 0 0 \% )}$ & $\mathbf{0 3 1 0 0 \% )}$ \\
\hline
\end{tabular}

\section{Discussion}

Adipose tissue tumors are the commonest soft tissue tumor in humans. ${ }^{[7]}$ Since most cases are diagnosed on light microscopy alone ${ }^{[1,8]}$ Ancillary diagnostic techniques have only a limited or occasional role, The actual incidence of lipoma is probably much higher than the reported incidence. This is not surprising, considering that most lipomas have insidious growth with localized mass effect. Many also only require a physician's intervention when they reach large sizes and cause cosmetic problems or complications due to anatomical location. ${ }^{[1,8]}$ The purpose of this study is to assess hospital based data of benign and malignant adipose tissue tumors with respect to age, sex, site distribution and to compare this with other similar studies.

Incidence of adipose tissue tumors in present study is 1.33 $\%$.lipomas are believed to arise from primordial adipocytes, not from adult fat cells, therefore increasing in size as a patient accumulates adipose tissue but not decreasing with weight loss. ${ }^{[2]}$ It has been documented in previous literature that lipomas might result from a previous trauma but Giuseppe Nigri et al 2008 reported that the trigger mechanism is activated by cytokine and growth factors released after the trauma with increase in thromboplastin time(PTT). ${ }^{[9]}$ Benign adipocytic tumors $(96.55 \%)$ are common in comparison of malignant ones( $3.45 \%)$. This observation is also seen in studies by Umar mohammad et al,(98\% Vs 2\%) Seleye-Fubara and Etebu ${ }^{[10]}$ and Weiss and Goldblum. ${ }^{[8]}$

Majority of cases of present study have been recorded in $30-50$ yrs age group followed by age $>50$ yrs followed by $18-30$ yrs age group. Which is also seen in Umar et al study? The slight female preponderance in this study is in consonance with other studies.$^{[1,7,10,11]} \mathrm{A}$ few studies, however, have documented a higher prevalence in males. ${ }^{[8,12]}$ Conventional lipoma was the most common benign adipocytic tumor seen in this study accounting for $85.06 \%$ of cases; followed by fibrolipoma (5.76\%) and angiolipoma (3.44\%) This finding is also in keeping with other similar studies. ${ }^{[1,7,12]}$ Lipomas rarely reach a size larger than 2 $\mathrm{cm}$. Lesions larger than $5 \mathrm{~cm}$, so-called giant lipomas, can occur anywhere in the body. ${ }^{[2]}$ Average size of benign lesion in present study was $4.8 \mathrm{~cm}$ whereas for malignant lesion average size was $5.6 \mathrm{~cm}$. No case of giant lipoma has been recorded in present study.

Lipomas are also known as 'ubiquitous tumors' as they are found in almost all fat containing organs of the body. ${ }^{[13,14]} \mathrm{It}$ can occur alone or in multiple locations. In present study, most favorable site for benign adipocytic tumors is the trunk (35.1\%) followed by lower $(23.81 \%) \&$ upper extremities (20.24\%). This pattern of anatomical distribution corroborates earlier reports. ${ }^{[1,7,10,12]}$ Liposarcoma, one of the common sarcoma of adults commonly appear in those aged between 40 and 60 years, and rarely in children. ${ }^{[15]}$ In present study, malignant cases (3.44\%) occurred in age group of more than $50 \mathrm{yrs} .^{[1,7,16,17]}$

\section{Conclusion}

In the present study, adipose tissue tumors contribute $1.33 \%$ of total yearly histopathological specimens. The incidence of benign adipose tissue tumors is much higher as compared to that of malignant ones. Ratio of benign to malignant adipose tissue tumors is $28: 1$.Commonest age group for benign tumors is $3^{\text {rd }}$ to $5^{\text {th }}$ decade $\&$ in malignant cases above 50 yrs. Benign tumors are more common in females while malignant tumors show higher incidence in males. M:F ratio of is $0.8: 1$ in benign soft tissue tumors \& 2:1 in malignant ones. Fibrolipoma is common benign variant. The most common site for occurrence of benign 
tumors is backside of the trunk and for malignant tumors are lower limbs.

\section{References}

1. Fletcher CD. Soft tissue tumours. In: Fletcher CD, editor. Diagnostic Histopathology of Tumours. 2nd ed. Boston: Churchill Livingstone; 2000. 1474-85.

2. B Allen, C Rader, A Babigian. Giant lipomas of the upper extremity. Can J Plast Surg. 2007;15(3):141-4.

3. Terzioglu A, Tuncali D, Yuksel A, Bingul F, Aslan G. Giant lipomas: A series of 12 consecutive cases and a giant liposarcoma of the thigh. Dermatol Surg. 2004;30:463-7.

4. Cribb GL, Cool WP, Ford DJ, Mangham DC. Giant lipomatous tumours of the hand and forearm. J Hand Surg [Br]. 2005;30:509-12.

5. Celik C, Karakousis CP, Moore R, Holyoke ED. Liposarcomas: Prognosis and management. J Surg Oncol. 1980;14:245-9.

6. Silistreli OK, Durmus EU, Ulusal BG, Oztan Y, Gorgu M. What should be the treatment modality in giant cutaneous lipomas? Review of the literature and report of 4 cases. Br J Plast Surg. 2005;58:394-8.

7. Rosai J. Soft tissue tumours. In: Rosai and Ackerman's Surgical Pathology. 10th ed., Vol. II. New York, NY, USA; Mosby an Imprint of Elsevier; 2011. 2140-5.

8. Weiss SW, Goldblum JR. Benign lipomatous tumours. In: Enzinger FM,Weiss SW, editors. Soft Tissue Tumours. 4th ed. Boston: Churchill Livingstone; 2001. 571-694.
9. G. Nigri, M. Dente, S. Valabrega, "Giant inframuscular lipoma disclosed 14 years after a blunt trauma: A case report," Journal of Medical Case Reports. 2008;2:318.

10. Seleye-Fubara D, Etebu EN. Adipose tissue tumour in Port Harcourt: A ten year review. Sahel Med J. 2005;8:92-4.

11. Leffert RD. Lipomas of the upper extremity. J Bone Joint Surg Am. 1972;54:1262-6.

12. Rydholm A, Berg NO. Size, site and clinical incidence of lipoma. Factors in the differential diagnosis of lipoma and sarcoma. Acta Orthop Scand. 1983;54:929-34.

13. C. Balakrishna, D. Nanavati, A. Balakrishnan, "Giant lipomas of the upper extremity: Case reports and aliterature review," Can J Plast Surg. 2012; XX (3):40-41.

14. C. Davis, J.G. Gruhn, "Giant lipoma of the thigh," Arch Surg. 1967;95:151-6.

15. Rosenberg AE. Bones, joints and soft-tissue tumours. In: Kumar V, Abbas A, Fausto N, editors. Robbins and Cotran Pathologic Basis of Disease. 8th ed. Philadelphia, PA. USA: Saunders Elsevier;2010:1249-50.

16. Enzinger FM, Winslow DJ. Liposarcoma. A study of 103 cases. Virchows Arch Pathol Anat Physiol Klin Med $1962 ; 335: 367-88$

17. Antonescu C, Ladanyi M. Myxoid liposarcoma In: Fletcher CD, Unni KK, Mertens F, editors. World Health Organization Classification of Tumours: Pathology and Genetics of tumours of Soft Tissue and Bone. Lyon: IARC Press;2002:40-3.

*Corresponding author:

Dr. Mayuri R. Gohil, 19, Shree Krishnapark Society, Near Iscon Megacity, Victoriya Park Road, Bhavnagar, Gujarat, India.

Phone: +91 9909903514

Email: drmayurigohil@Gmail.Com

Financial or other Competing Interests: None. 